The template for California's forest policies emerged at the beginning of the 20th century, a time of increasing federal power, global expansion and hard social distinctions. Of the state's $\mathbf{2}$ million or so people, few were eligible to vote and fewer still were interested in forests. Forest policy was the arena of a relatively small group. Today a similar, relatively small group controls California forests, but the political base for their control is eroding. California's diverse and democratic society of 35 million people no longer conforms to the wishes of any forest elite, be it scientific, governmental, industrial or environmental. Yet the state's forest elites continue to arm-wrestle as though the old social structure still held. California citizens, meanwhile, have organized hundreds of watershed groups in neighborhoods and communities statewide, supporting goals such as salmon recovery, urban access and local economic opportunity. These actions represent a massive spontaneous change in political culture. The simple choices of $\mathbf{2 5}$ or $\mathbf{5 0}$ years ago, of preservation versus use, public versus private, no longer encompass the interests of California's population. By 2025, a highly diversified landscape of forest institutions, management techniques and ecological conditions will soften current jurisdictional distinctions. The people who come to the table to discuss forest policy will no longer be just the elites who shaped forest policy in the 20th century. Whether we are better off or not will depend on how aggressively the state pursues the innovations necessary to sustain cohesive and resilient forest systems serving larger public Interests.

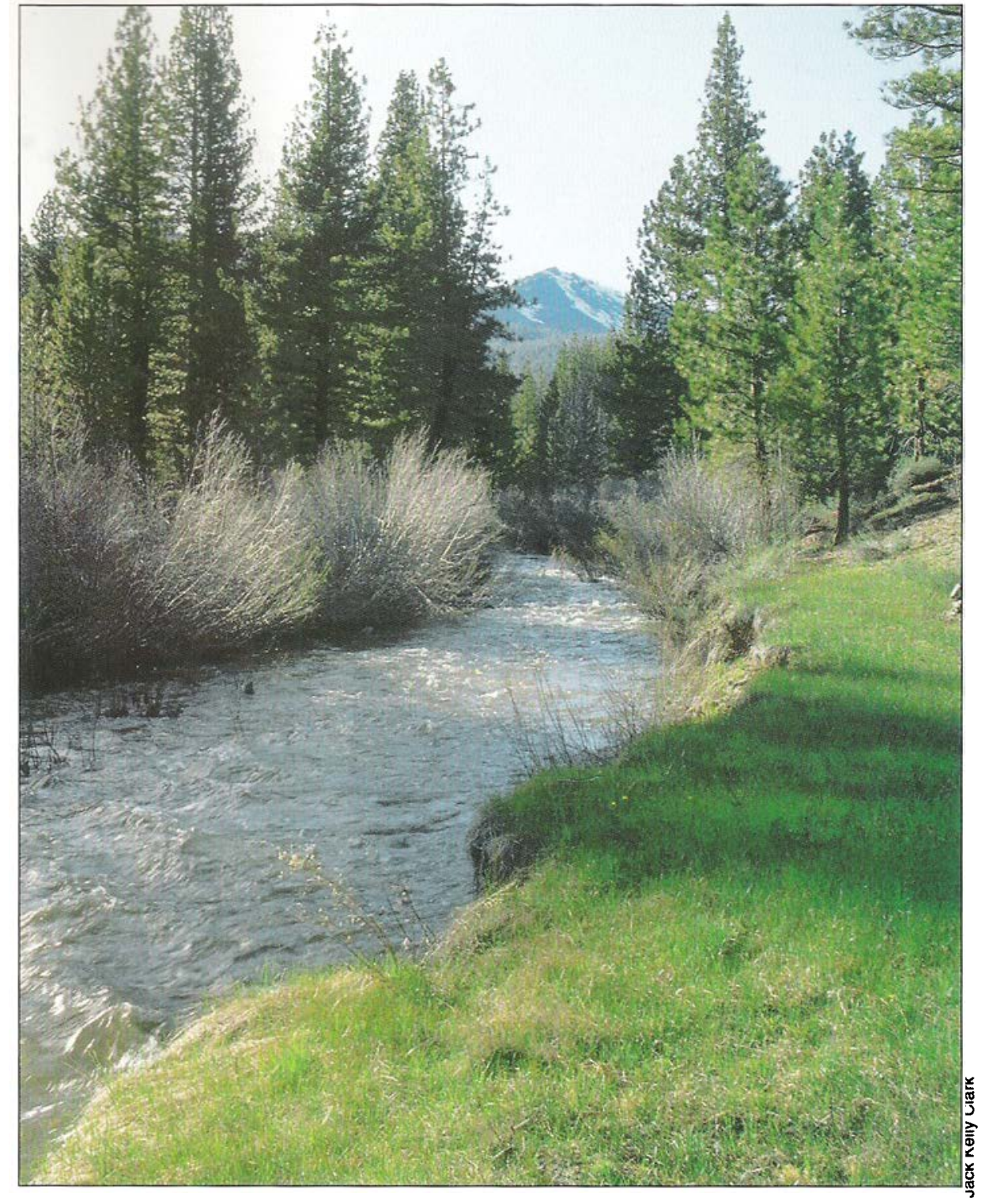

For most of the 20th century, forests were viewed as timber forests or park and wilderness preserves. In the 21 st century, the public is redefining them as water forests, habitat forests, production forests, science forests, urban forests or in other ways.

\section{California forest policy must bend toward the new social order}

\author{
Jeff Romm
}

Today's forest policies reflect the is1 sues and interests of a century ago when California held center stage in the nation's Progressive Era drama (Pinchot 1946; Kelley 1998). Around the turn of the century, water battles were taking shape in the Owens Valley (Kahrl 1982; Walton 1992) and at the future site of the Hetch Hetchy Dam (Muir 1912) that would profoundly affect California's future. In forestry, John Muir (favoring pure voring exploitation) and Gifford Pinchot (the first chief of the U.S. Forest Service [USFS], who favored scienpreservation), the Timber Barons (fa- 


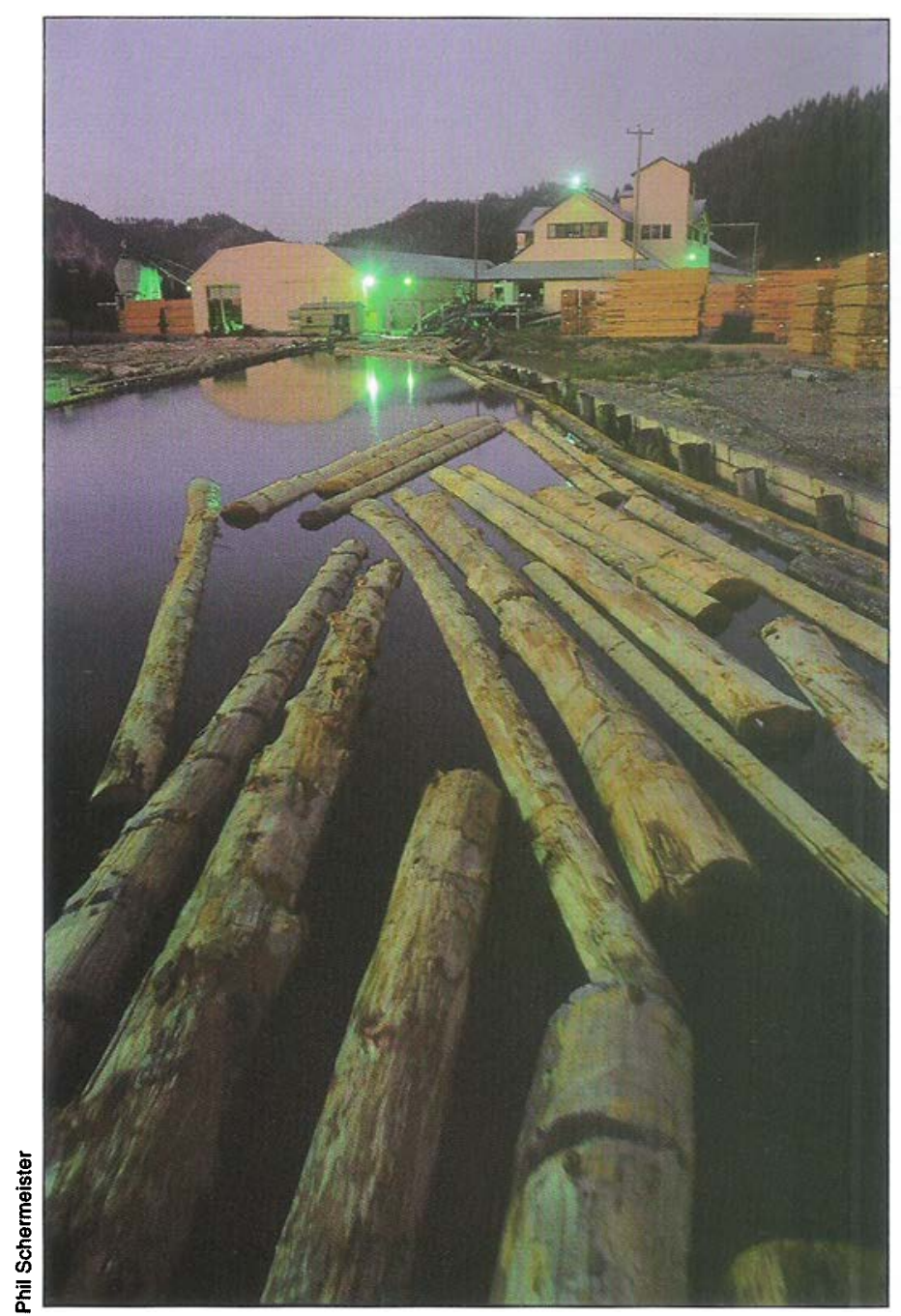

Political boundarles no longer constrain international trade. Today, California mills may process logs from New Zealand or elsewhere.

tific federal management) were engaged in a monumental struggle for control of the state's vast forests, a morality play which unfolded over the course of the 20th century. This tale is retold around the contemporary campfires of conference tables, at meetings of federal and state forestry officials, industry representatives, university faculty and environmentalists, as if to reaffirm the group's commitment to a history and place that make sense.

But this story of three groups battling over the nation's forests does not encompass recent trends: the new groundswells of citizen activism, and the concurrent impacts of globalized trade and mobility of people, environmental impacts and information. The old story assumes an ascendant federal power, elite white-male politics and weak international influences. It assumes that good government protects people from themselves, restraining them from destroying nature. It assumes impartial and authoritative science. And it misses three forces that have created new possibilities in the 20th century: (1) the decline of federal versus state territorial power, and the decline of both relative to specialized instruments of policy such as water- and air-quality standards and endangered species protections; (2) the diversification, democratization and spread of California's populace; and (3) the dissolution of America's national borders.

Political boundaries no longer restrain international movement or commerce. Logs from New Zealand go to mills in the Sierra Nevada. Our forest workers come from Uruguay, El Salvador and Indochina. We can now sell our products anywhere in the world, and participate in international negotiations on climate, energy, biodiversity, salmon, water and forests. The nation's interior borders, such as boundaries around federal lands, are also changing and dissolving. For example, Laotians are collecting mushrooms in federal forests and selling them to Japan through various market channels. The state has authority to regulate water-quality impacts of federal forest practices, and local groups are taking steps to restore streams and reduce fire hazards on federal lands. The USFS staff is half the size it was 10 years ago, meaning these employees are no longer a strong presence on the land they must man- age. The agency depends increasingly on the cooperation of others. In the next quarter-century, we will be challenged by growing tension between the established institutions of forest policy and these newer social realities.

\section{From federal power to transboundary cooperation}

The Pinchot-Muir-Barons drama of federal ascendancy explains why, at the turn of the last century, the federal government set aside 30 million acres in California as national forests, parks and other reserves (CDFFP 1988). With subsequent extensions of the federal reserve concept to deserts and grasslands, half of the entire state - about 50 million acres - is now under some form of federal ownership (CDFFP 1988). But from the 1920 s onward, federal support for state activities with respect to private lands began to produce a rich and diversifying pattern that sharpened, and then swept over, the distinctions between federal and private domains. Fire and pest control, reforestation, planning, research and education developed as federal-state cooperative endeavors. By the 1980s, California had achieved strong managerial and policy control on private forests, comparable to the federal government's control of national lands. Moreover, the reliance of federal air- and water-quality laws on state authority and implementation opened even federal lands to state policy influence.

By the 1990s, the most forceful forest authorities were not territorial like those of USFS or U.S. Bureau of Land Management, but those charged with implementing specific federal and state environmental standards. For instance, the National Marine and Fisheries Service, charged with protecting marine fisheries under the Endangered Species Act, is enforcing salmon habitat standards on a wide variety of land and water users in Central and Northern California. The regulatory impact has run hundreds of miles upstream into the Sierra Nevada. It is af- 
fecting farmers, ranchers, timberland owners, vineyard owners, subdivision developers, county road-builders and the national forests.

Instead of relying on federal, state or local jurisdictions, such specialized instruments created precise standards to which all authorities had to adjust. As territorial borders softened, state authorities gained increasing influence within federal jurisdictions. For example, the State Water Resources Control Board today has approval authority for best management practices on federal lands. Strict standards for endangered species and water-quality protection have provoked massive social and economic disruptions, such as a $75 \%$ reduction in logging on national forests and serious job loss in forestdependent communities. They have also led to innovative reforms (such as watershed and biodiversity councils, and habitat conservation plans) in our land and water institutions.

Other factors have further fragmented territorial coordination, such as the diversification of markets for nonwood forest products, including foods, medicinals and ornamentals. Ironically, the public is also calling for territorial integration through, for example, 'ecosystem,' 'regional,' 'watershed,' 'habitat' and 'community' resource management. These concepts bear little relation either to existing jurisdictional boundaries or to diverse social influences that may converge in a place. The resulting turmoil has eroded the legitimacy of established forest institutions (the USFS and the State Board of Forestry in particular), but has not yet generated a clear vision of alternative means to satisfy the demands for regional integration.

State and local governments, and nongovernmental organizations, have sought means to create public territorial governance that integrates forests and people in new ways. Examples include:

- The Quincy Library Group.(QLG) regional plan for northeastern California.
- Watershed organizations that now pervade the state, such as cooperative biodiversity councils at regional and state levels (Klamath Biodiversity Council being the most noteworthy).

- The growing number of communitybased, restoration-oriented forest stewardship endeavors, such as those of the Plumas and Humboldt county development corporations, and the cooperative resource management plan groups for the Feather and Mokulumne rivers. Rather than territorial ownership, these approaches focus on cooperative solutions to ecosystem management issues and on the qualities of the larger landscape or region.

\section{From narrow to cosmopolitan politics}

The Pinchot-Muir-Barons history evokes a "top-hat and lace" era, which happened to exclude women, Native Americans, workers, racial minorities, farmers and grazers from the policy arena (McWilliams 1944; Allen 1974; Weber 1994; Almaguer 1994; Gyory 1998). Today, these constituencies have come out of the woods to surround those at the campfire.

Moreover, this diversification and empowerment has occurred as urbanization was pulling people out of the countryside during the first half of the century, then returning them - with more money, education, urbanity - in the second to form rural cities, suburbs and anticity settlements. Cities have spread over California to dominate all but a few counties. Not one county remains in which forestry is the primary economic base; virtually all forested counties derive their primary income from retirees and recreationists. Even Del Norte County relies on prisons for its primary employment. If "rural" California includes all but the Bay Area and Southern California, it has a larger urban population than at least 40 states (US Statistical Abstract 1999).
Every acre of forest is viewed as part of the natural infrastructure that supports urban life, supplying and cleansing water, regulating air quality and climate, providing energy and materials, and sustaining open space for enjoyment.

The state's forests have been absorbed in a vast California metropolis. Every acre of forest is viewed as part of the natural infrastructure that supports urban life, supplying and cleansing water, regulating air quality and climate, providing energy and materials, and sustaining open space for enjoyment. Management of California's forests today is increasingly influenced by the interests of a highly urbanized, ethnically diverse population, in which people of color are the emerging majority (Clark 2000). The work of planting forests, as well as cultivating, thinning, harvesting, restoring and protecting them, is more likely to be done by racial minorities and women, often settled in towns and cities, than by the stereotypic white camp logger or mill town resident. Mexican farmworkers and farm labor contractors are extending their work years to include forest activities. Fire and planting crews have a substantial proportion of women and Native Americans.

The combination of urbanity, ethnic diversity, environmental sensibility and economic need are creating new centers of political power within and about forests. In many forest towns, citizens have reached consensus on a political agenda that crosses the spectrum, including environmental restoration, job creation and equitable distribution of benefits from forests. 
Likewise, in Southern California, groups like Mothers of East Los Angeles, TreePeople, the California Department of Forestry and the USFS are working together to create neighborhood forests, schoolyard watersheds and stewardship programs that involve city kids. In the Gnatcatcher Habitat Management Plan on the Southern California coast, four counties are cooperating with banking and real estate interests and with state and federal agencies to preserve endangered habitat in the midst of urbanization. In the Bay Area, Greenbelt Alliance and other organizations are focusing on strategic relationships among suburban preserves, inner-city housing costs and congestion, and urban sprawl into agricultural and forest areas.

\section{From strong to weak borders}

The third fundamental change is the opening of California's borders to the outside world, as part of the globalization process. At the beginning of the century, the United States was emerging as an imperial power with acquisitions in the Far East and Caribbean (Wiebe 1967; Woodward 1971; Karnow 1989). After World War II, the high borders of Cold War blocks and independent nations replaced the imperialist system. And by the 1990s, after the walls of the Cold War world had collapsed, a proliferation of the pathways through which goods, money, people, culture, technology and associated political arrangements move had dissolved national borders and penetrated directly to virtually every spot in California (Reich 1992).

The drop in national borders creates a situation in which groups try to establish new forms of governance to protect what they want for their futures. This phenomenon is reflected in current movements toward community, watershed, ecosystem and regional modes of resource governance; emphases on partnerships, cooperation and consensus; realignments of corporate landholdings; and the rise of

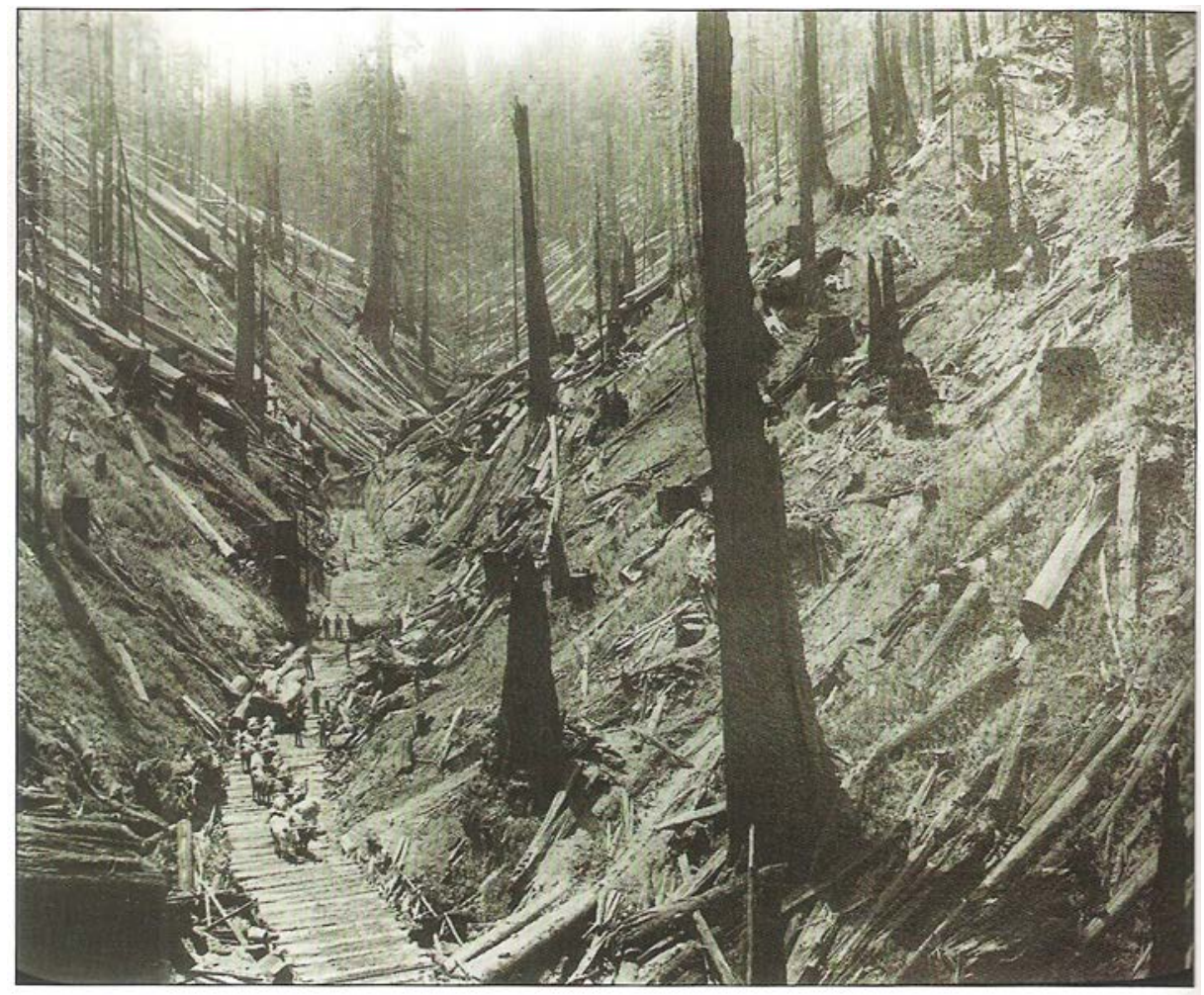

new forms of workers' organizations.

Forest policy faces particular problems because its history is so rooted in clear territorial and social distinctions. National borders are weakening at the very time that ownership and jurisdictional boundaries can no longer protect against these external influences.

The authoritativeness of "scientific management" has given way to a fuller consideration of the diversity of perspectives and interests in forest policy. Every forest town now has someone who is capable of soundly challenging mainstream science and professional judgment. In Yuba and Mendocino counties, for example, people used home computers to simulate forest dynamics and produce valid alternatives to agency and academic models and plans. Information, ideas and expertise move almost instantly to a forest community from across the globe. In Trinity County, citizens of Hayfork have drawn advice from India regarding how to cooperate with territorial forest departments, and have provided ideas in return to people in the Philippines with similar problems.

As local citizens mobilize to assert and protect their forest interests, their varying viewpoints illustrate the challenges that community differences create for forest policy. Some communities, such as Quincy and Hayfork, envision themselves at the node of regional forest arrangements that cross proprietary and jurisdictional lines. Others - such as the Klamath Council and the Mattole - focus on natural habitats or - as with the Round Valley and Hupa Reservations and Sinkyone Council - on cultural sites they protect. Still others - like the Institute of Sustainable Forestry in Piercy, Mendocino County, and the Alliance of Forest Workers and Harvesters - focus on forest-derived market employment and enterprise. The towns of Arcata, Berkeley, Chico and San Jose have been concentrating on urban creek restoration, with help from rural groups. Each and every one of them has a different version of proper boundaries and the rules that should apply.

This divergence of interest creates its own problems in a highly mobile society that continues to rely on 'outsiders' to sustain economic and environmental viability. Outsiders - visitors, new residents, migrant workers, minority residents - bring much of 


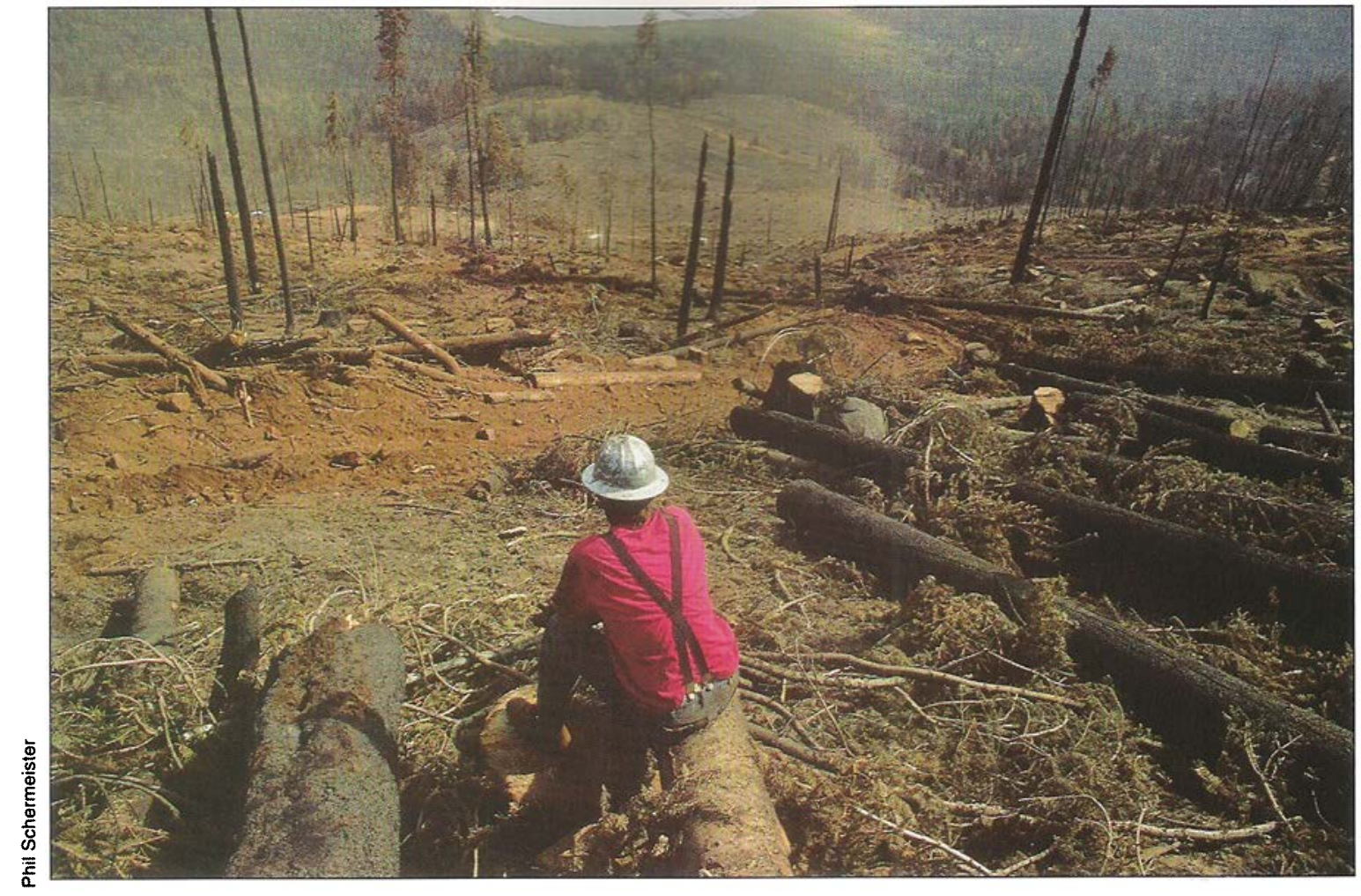

Historically, decisions concerning forests and timber harvesting were made by a small and powerful elite. Today, decisions are more likely to be reached by a process of consensus-building among local stakeholders, environmentalists, scientists, regulators and other interested persons. At left, Near Burney, a salvage logger surveys the landscape. While logging in national forests has declined $75 \%$, clearcutting, historic photo, facing page, still occurs on public and private lands.

the money and do much of the work. Race and ethnicity isolate workers, resident or mobile, from the communities that rely on them. As California moves toward a political majority of minorities, the disparity between localized exclusion and state-level inclusion of minority interests is likely to challenge forest institutions to become much more inclusive and adaptable.

\section{Realities of the 21st century}

The 20th century bestowed a fresh set of possibilities which challenged established policies and institutions. In general, regulatory emphasis has shifted from public control of specific actions, such as logging a particular site, toward public commitments to regional outcomes, such as water quality or habitat restoration. This shift should gradually increase the freedom of people to act in their best interests as long as they fulfill clear standards of viability for endangered species, biodiversity, water quality, sustainable forests and other public interests.

There is a related shift from dependence on administrative-scientific prescription to beneficial exchangẹs among diverse interests. This is occurring along with a diversification of valued forest goods and services that far exceeds administrative capacities to absorb, manage and use information. While timber has traditionally been the major asset of forests, financial exchanges now occur for the provision of water, water quality and water storage (e.g., Santa Barbara pays USFS for rotational burning upstream from its reservoir [Baker and Romm 1990]); preservation of old growth, riparian sites, habitats, threatened species and biodiversity (e.g., public purchase of Headwaters Forest,

conservation easements for site protection, habitat mitigation purchases by developers); foods and medicinal and ornamental plants (e.g., harvest and sale of mushrooms, St. Johns wort and salal wreaths); recreation and open space (e.g., hunting concessions, open space trusts).

This shift reflects the 20th-century lesson that protective restraints in one jurisdiction can increase pressure on unprotected resources in another, with seesaw consequences that often defeat the purpose of restraint. Early protection of the national forests transferred harvest pressures to private lands, contributing to their decimation. Later strengthening of state restraints on pri- vate forests contributed to post-World War II pressures on federal forests. Endangered species protections have increased cutting of nonindustrial private forests. Forest protection zones, in which subdividing is prohibited, have increased the development value of adjacent lands. The shift toward financial or other exchanges to protect and manage whole ecosystems reflects a growing recognition that accommodations must be made across boundaries.

Forest policy discourse has become dominated by popular concepts of community, council, region, partnership and cooperative agreement, typically relying upon consensual rather than majority decisions. Occasionally, these ideas even seem to override and strain the electoral governments of representative democracy. In one case, a majority decision by the elected Mendocino County Board of Supervisors to establish local forest practice rules was criticized at the state level as not reflecting a county consensus.

While for most of the 20th century forests were viewed as timber forests or park and wilderness preserves, the new public arenas are defining, for example, water forests, habitat forests, production forests, science forests, cul- 


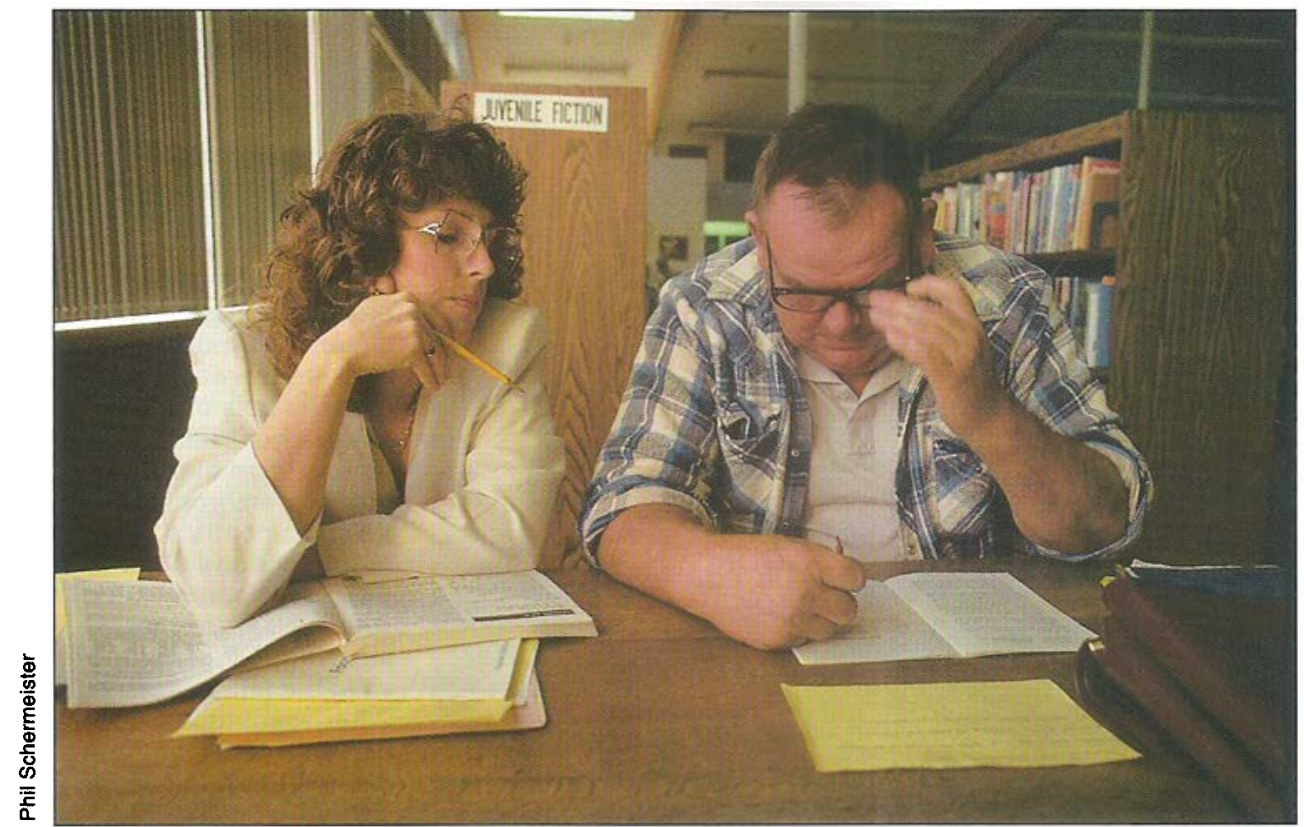

Decisions about forests are more complex than, for example, jobs versus spotted owls, but human impacts cannot be ignored. In Red Bluff, a laid-off mill worker considers his options.

tural forests, carbon forests, community forests, health forests, urban forests, biodiversity forests, school forests, and almost infinite mixes of the overlaps among these in different landscapes and social settings. These emerging classifications and mixtures share a common disregard for conventional lines of jurisdiction and ownership.

Modes of governance are needed that define desired outcomes and standards rather than undesired acts; rely on incentives rather than restraints; create the opportunities needed for parties of interest to negotiate means to desired ends; and develop relations among levels of governance that improve adjustments among different constituencies and the interdependent forest conditions they prefer.

State government is in the crucial position to assume leadership. The state has the unique potential to mediate between federal and local interests, between public and private jurisdictions, and between territorial and specialized authorities, and to coordinate actions toward wateroriented and urbanization-driven forests.

\section{Toward 2025}

Those who identify with the campfire of Muir, Pinchot and the Barons still may see themselves at odds with one another in disputes that represent the broad public interest (Wilkinson 1992), but they have become too small and select a group to presume that is so. The institutions they spawned in the 20th century - USFS, State Board of Forestry, professional schools, the forest industry, the environmental establishment - for all their virtues, no longer express the span of public interests and needs in the global 'state-nation' of California. The timber industry, the environmental establishment and the professional forestry agencies together have grown embattled, demoralized, doubtful and defensive, deferring to the old century's policy reflex of restraint against others. Today, the established order is proficient in an ever-declining realm.

However, California forest policy has also become a scene of vibrant innovations that suggest opportunities as well as stifling overburdens. There are now many efforts that demonstrate how the virtues of imagination, flexibility, trade and a positive attitude about human moti- vations, can prevail in the uphill battles against a defensive, established order.

Some of these innovations are remarkably influential. In 1990, for example, the Institute of Sustainable Forestry (ISF), then in southern Humboldt County, recognized that its attempts to promote sustainable forestry among small landowners required the capacity to pay them for their efforts. It developed the idea of market certification of wood products that came from certified sustainable forests. The idea has grown into a worldwide movement. The Forest Stewardship Council, an international body, accredits thirdparty certifiers, such as the ISF's Smartwood and Oakland's Scientific Certification Systems, who then certify ownerships that are managed sustainably, foresters who manage groups of ownerships sustainably, and mills that process certified material. Large-scale corporate and public ownerships have been certified in Scandinavia, the Amazon and throughout North America. Consumers who go to Home Depot now have the opportunity to choose between wood that is or is not certified. A book or magazine that is published in Europe is very likely to be made of certified materials (MacArthur Working Group 1998).

Intergovernmental relations. Brittle and competitive relations between federal, state and county governments undermine responsive and accountable governance of transboundary forests. For example, riparian forests continue to deteriorate under fragmented responsibility despite popular support for their restoration. Regional production forests, in the Sierra-Cascade region for example, are another place where jurisdictional lines set a century ago are given more credence than today's markets, demographics, technologies and politics. The community-based plans and regional councils we have mentioned offer evidence of the range of better alternatives. 
A new intergovernmental compact - that is a new framework for federalstate-local relations - is needed to gain adaptable and complementary policy commitments among governments that interact to shape forest conditions. Rather than our hierarchical understanding of these relations, the new compact would distribute authorities and responsibilities more evenly and would emphasize means for systematic cooperation. This has been accomplished in matters of fire protection, but is needed across all dimensions of natural-resource management. Public interests in water, wood, wildlife and healthy communities, for example, simply cannot be satisfied in the absence of such reform.

Forest agencies. Pivotal 20thcentury institutions have narrower political, legal and scientific foundations than they need to serve an increasingly complex California. The disparity between what they were created to do and are now able to do has reduced them essentially to agents of whichever political interests are in power. Changes are plausible. The scientific and political reach of agencies can be broadened to regain public legitimacy. USFS is accomplishing this through cooperation with forest communities and cities outside federal lands; the established forest agencies can also be replaced or augmented by others with specialized mandates to address broader-scale forest issues.

Likewise, the CALFED process for state water storage, yield and allocation must also incorporate forests in considerations of state water supply. The Tahoe Regional Planning Authority and cooperative agreements among Central Sierra counties shape forest conditions through and for their management of urban growth (Erman et al. 1996). It remains to be seen whether such developments will continue to occur on a costly ad hoc basis or whether broader, systemic reforms can be achieved.

Forestry education and research. Universities, the state's source of pro- fessional and scientific forestry leadership for most of the 20th century, have lost their capacity to provide the vision for reform. Pressed to defend the past as well as create new opportunities for the future, these universities have largely split these two functions between professional and scientific academic departments. This dichotomy is expanding the pool of forest scientists, diversifying inquiry, and improving research quality, but it leaves a vacuum in integrative applied education and research that the established professional programs seem reluctant to fill. Students who want professional careers in riparian forestry can choose from perhaps 10 different majors in the UC and CSU systems, not one of which provides the diversity, depth and judgment that professional forestry requires. No academic department generates truly integrated, applied knowledge of riparian systems, regional production forestry, metropolitan or community forestry, and other future needs. The slow emergence of suitably trained young professionals is a fundamental restraint on institutional reform. Pancampus faculties and centers of forestry, such as the UC Center of Forestry, the DANR Forestry Working Group, and Board of Forestry initiatives among UC and CSU faculty, are valuable steps toward mobilizing expertise, and must continue to evolve toward vigorous regional and statewide systems that shape the future rather than preserve the past.

Security and private investment. Private investment is an irreplaceable

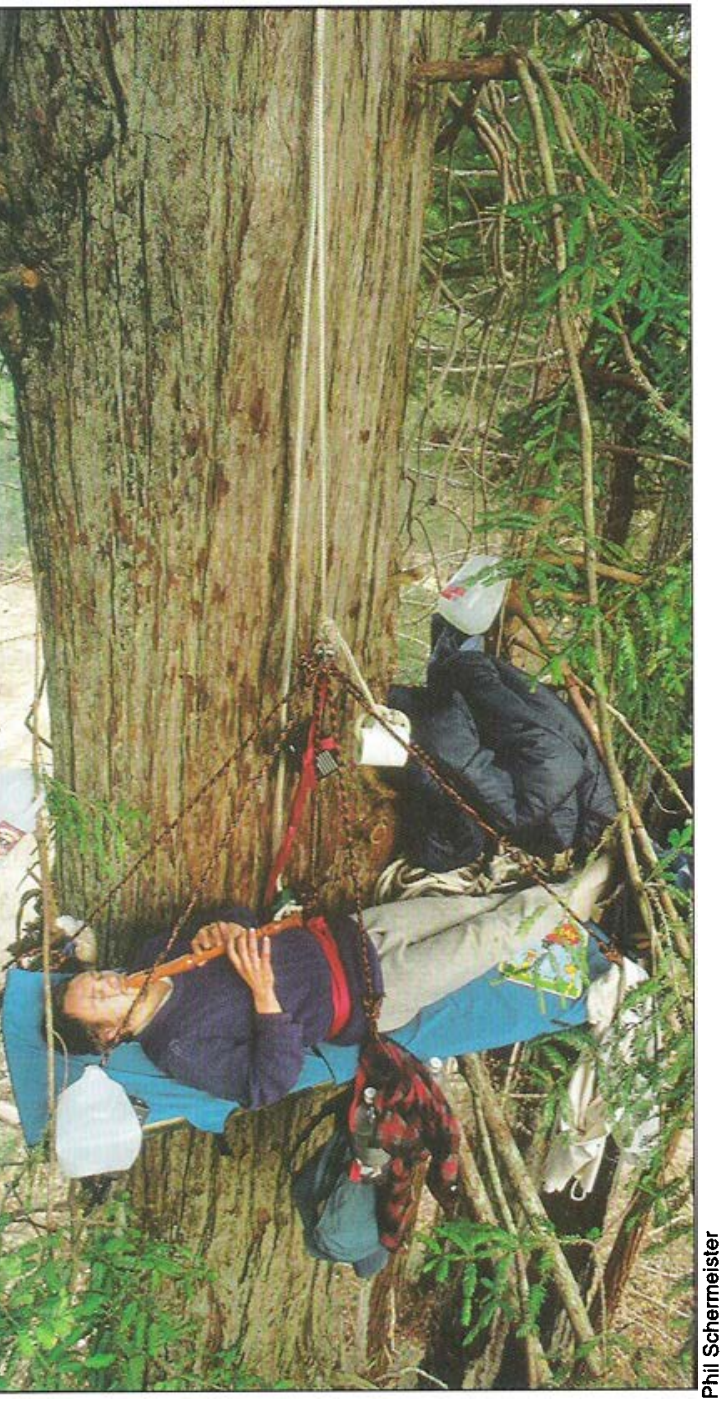

Tree-sitting has long been a tactic used by activists on California's North Coast to focus public attention on the destruction of ancient redwood trees. Above, An Earth Firstl activist named Albion passed the time in 1993.

feature of forest sustainability in California. The public interest lies increasingly in the condition of forest and ecosystem processes, with consequences that weaken the rights of private as well as public forest owners. If private investment is to be sustained, improved security of investment and opportunities for trade must compensate owners for their loss of control over how their land is used. Easements, trusts, forest banks, low-interest credit and long-term pacts among owners and with public regulators, are examples of promising innovations that pay private owners to provide public 
services for forest-related services. The state has crucial roles as a broker, such as in the sale of private watershed or preservation services; as financier and coordinator of public investment, such as in the water-storage capacities of river basins or in the forest infrastructure of metropolitan systems; and as regulator of markets in forests, land and water.

\section{Future in focus: Innovation and enterprise}

Today's trends could reverse, bringing a federal resurgence, strengthened restraints on social mobility, and greater protection of national borders. Or, the old structure could stand fast despite declining relevance, occupying ever smaller corners of the social arena in which forests are managed. While both of these possibilities may materialize to some small degree, innovation and enterprise are pervasive in California and will lead to fundamental changes within 25 years.

California forest policy will shift from the regulation of land ownership toward the facilitation and enforcement of social exchanges that achieve forest impacts and conditions that people value. In particular, the state's role will expand to include creating and mediating trade, coordinating federal and local interests, and consolidating the expertise and finance needed to treat forests as features of metropolitan water and habitat as well as regional production and preservation systems. A multicentered structure of state forest governance - with strong nodes in water, urban development, production forestry and preservation - will emerge to integrate the influence of relevant agencies, provide specialized expertise, serve varied constituencies and form intergovernmental arrangements.

Water and urban development represent vast configurations of public powers and interests in forests that are not expressed in the current formal forest-policy structure. Spontaneous innovation and governmental adaptation have revealed the opportunities, means and constraints involved in achieving effective resolutions.

As cooperation becomes more pervasive in forest policy, the market impacts of forest restraints - specifically the price impacts of withholding potential supplies of goods and services - will be forced into the light and developed explicitly to attain public ends. The use of forest zones to govern adjacent land values, and species protections and riparian reserves to govern incentives for forestry investment or water conservation, are examples of experiments that have already occurred but that have not been analyzed for the impacts they spread through market processes.

The current mobilization of forest communities and workers, the sources of the tangible effort and energy in and about the forest, will bring them into the policy circle after a century of Progressive denial that healthy environments are more than ideas, laws and agencies. Healthy environments take immense work and depend upon people to do it. In Quincy, Hayfork and the Yuba River, forest communities are demonstrating why the care they provide for the forest sustains essential public services, why the skills they develop and the relationships they broker make the difference between opportunity and decline, why their relief of disputes and limitations of the old order create fresh pathways of innovation.

The political culture of California is imaginative and diverse as well as protective of privilege, and the tensions between the old and new policy schools are not confined to forestry. But forestry has features that have resisted innovation perhaps more than any other sphere of state life. The dam has weakened, and the trickle of innovations is becoming a flood. The future of California's forests depends on whether new configurations can emerge which incorporate the state's diverse people and interests, and the extent to which state government fills the vacuum of financial and political leadership left over from days gone by.

J. Romm is Professor and Chair, Resource Institutions, Policy and Management, College of Natural Resources, UC Berkeley.

\section{References}

Allen R. 1974. Reluctant Reformers. Washington, DC: Howard University Press. 324 p. Almaguer T. 1994. Racial Fault Lines. Berkeley, CA: UC Press. $281 \mathrm{p}$.

Baker M, Romm J. 1992. Emerging Watershed Institutions in California. California Department of Forestry. Forest and Rangeland Resources Assessment Program. Sacramento, CA.

[CDFFP] California Department of Forestry and Fire Protection. 1988. California's Forests and Rangelands: Growing Conflict Over Changing Uses. California Forest and Rangeland Resources Assessment Program. Sacramento,

CA. 348 p.

Clark WAV. 2000. Immigration, high fertility fuel state's population growth. Cal Ag 54(1):11-8.

Erman D. et al. 1996. Sierra Nevada Ecosystem Project Report. Wildland Resources Center, UC Davis. Vol. I, p 48-60.

Gyory A. 1998. Closing the Gate. Raleigh: University of North Carolina Press. 354 p. Kahrl W. 1982. Water and Power. Berkeley, CA: UC Press. 583 p.

Karnow S. 1989. In Our Image: America's

Empire in the Philippines. NY: Ballantine. $494 \mathrm{p}$. Kelley R. 1998. Battling the Inland Sea. Berkeley, CA: UC Press. $395 \mathrm{p}$.

MacArthur Working Group. 1998. The Business of Sustainable Forestry. Chicago:

MacArthur Foundation.

McWilliams C. 1944. Prejudice. NY: Little

Brown. $337 \mathrm{p}$.

Muir J. 1912. The Yosemite. NY: Century. Pinchot G. 1946. Breaking New Ground.

NY: Harcourt Brace. $522 p$.

Reich R. 1992. The Work of Nations. NY: Vintage. $339 \mathrm{p}$.

US Statistical Abstract. 1999. US Census

Bureau. State population estimates.

www.census.gov/statab/www/part6.html Walton J. 1992. Western Times and Water

Wars. Berkeley, CA: UC Press. 378 p. Weber D. 1994. Dark Sweat, White Gold.

Berkeley, CA: UC Press. $344 \mathrm{p}$.

Wiebe R. 1967. The Search For Order,

1877-1920. NY: Hill \& Wang. 333 p. Wilkinson C. 1992. The Eagle Bird. NY: Pantheon. 201 p.

Woodward V. 1971. American Counterpoint. Oxford. $301 p$. 